\title{
RECORDS OF FRANCISCANA (PONTOPORIA BLAINVILLEI) FROM THE COASTAL WATERS OF SÃO PAULO STATE, SOUTHEASTERN BRAZIL
}

\author{
Marcos C. O. Santos ${ }^{1}$, André F. C. Vicente ${ }^{2}$, Émerson Zampirolli² ${ }^{2}$ Fernando S. Alvarenga² and Shirley P. Souza ${ }^{3}$
}

\begin{abstract}
Little is known about franciscana (Pontoporia blainvillei) in the coastal waters of São Paulo State $\left(\sim 23-25^{\circ} S\right)$, Brazil. This is due to the lack of long-term research efforts directed towards this species. The data presented in this paper reflect the efforts of three research groups in collecting information from marine mammal stranding events along portions of São Paulo State coast. Data from 109 records, mostly of single stranding events $(\mathrm{n}=98)$, are presented. Ten individuals that were captured incidentally by gillnets were obtained from local fishermen. One calf was caught by a swimmer in shallow waters and released after four hours. The number of reported strandings was not evenly distributed throughout the year with more strandings being reported during summer, spring and winter months than in the autumn. Calves $(n=28)$ were reported year-round with no significant seasonal differences. Six live strandings of calves were reported. Five of these calves died shortly after being held in small pools and one was released alive in coastal waters. Because of recent efforts in research and recovering of a relatively high number of dead animals, the easy accessibility to carcasses and local logistics, the central region of São Paulo State coast, known as "Baixada Santista", offers the best potential to better develop P. blainvillei research.

Resumo - Pouco se sabe sobre a toninha (Pontoporia blainvillei) ao longo da costa do Estado de São Paulo ( 23-25ㅇ), Brasil. Isso ocorre em função da falta da aplicação de esforços de observação de longo prazo direcionados a esta espécie. Os dados reunidos e apresentados neste trabalho referem-se aos esforços de observação de três grupos de pesquisa que estão coletando informações provenientes de eventos de encalhes de mamíferos marinhos ao longo de sub-setores do litoral paulista. Um total de 109 registros são apresentados. A maioria deles foi reportada através de encalhes individuais $(n=98)$. Dez indivíduos que foram capturados acidentalmente em redes de pesca foram obtidos através de pescadores. Um filhote foi retirado de águas rasas por um banhista e liberado após quatro horas. O número de encalhes observados não foi constante ao longo do ano, sendo mais elevados nos meses de verão, inverno e primavera do que no outono. Filhotes $(n=28)$ foram reportados ao longo de todo o ano, sem picos sazonais de ocorrência. Dos registros de encalhes, seis filhotes foram encontrados vivos: cinco morreram após permanecer em pequenas piscinas por até 36 horas, e o remanescente foi liberado vivo em águas costeiras. Em função de uma implementação nos esforços de observação - responsável por recuperar um número elevado de exemplares encalhados -, o fácil acesso a esses exemplares e a logística local, a região central do Estado de São Paulo, conhecida como "Baixada Santista", concentra o principal potencial para o desenvolvimento da pesquisa com P. blainvillei.
\end{abstract}

Keywords: Franciscana, Pontoporia blainvillei, strandings, São Paulo State, western South Atlantic.

\section{Introduction}

The franciscana dolphin, Pontoporia blainvillei, is endemic to the coastal waters of the Western South Atlantic, from Província de Chubut (42³5'S), Argentina (Crespo et al., 1998) to Itaúnas $\left(18^{\circ} 25^{\prime} \mathrm{S}\right)$, Espírito Santo, Brazil (Moreira and Siciliano, 1991). Knowledge of this species' biology has come mainly from studies undertaken in Uruguay and southern Brazil, beginning in the 1970s (e.g. Fitch and Brownell, 1971; Brownell, 1975; Kasuya and Brownell, 1979; Pinedo, 1991; Moreno et al., 1997; Secchi et al., 1997, 1998, 2001). Most of these investigations were conducted on dolphins that were captured incidentally. Since the late 1980s and early 1990s, research projects were established along the northern coast of Rio de Janeiro (e.g. Di Beneditto, 1997; 2000; Ramos, 1997; Ramos et al., 2000) and along the northern coast of Paraná (e.g. Zanelatto, 1997; Rosas, 2000). In other areas, research programs have only recently begun. One of these areas is the coast of São Paulo State $\left(23^{\circ} 18^{\prime} \mathrm{S}, 44^{\circ} 42^{\prime} \mathrm{W}\right.$ to $25^{\circ} 14^{\prime} \mathrm{S}$, $\left.48^{\circ} 01^{\prime} \mathrm{W}\right)$, southeastern Brazil. São Paulo's coastline is about $600 \mathrm{~km}$ long and faces the Western South Atlantic Ocean (Figure 1). The northern portion of São Paulo is characterized by rocky shores, small bays and about 60 islands, which are located between 0.07 and $38 \mathrm{~km}$ from the coast (Besnard, 1950; SMA, 1999). The main cities are Ubatuba, Caraguatatuba, characteristics. It is heavily populated, industrialized and hosts the largest harbour in Latin America, Porto de Santos, at Santos Bay (CODESP, 1992). There is a large expanse of mangroves (Besnard, 1950) but the local estuarine waters are heavily polluted (SMA, 1999). The main cities are Santos, Guarujá, Praia Grande, Mongaguá, Itanhaém, Bertioga and Peruíbe. Long and sandy beaches that protect the approximately $85 \mathrm{~km}$ long Cananéia estuarine system characterize the southern coast of São Paulo State (Besnard, 1950; Schaeffer-Novelli, 1990). The inner waters wash a mangrove area of about $90 \mathrm{~km}^{2}$ (Schaeffer-Novelli et al., 1990). The main cities are Iguape, Cananéia (coupled with Ilha do Cardoso) and Ilha Comprida.

The first confirmed record of $P$. blainvillei from the coastal waters of São Paulo was presented by Carvalho (1961), who reported the incidental capture of two individuals about $100 \mathrm{~km}$ from the coast of Santos during two different occasions. Morphometrics and osteology were presented. Carvalho (1961) referred to the franciscana as Stenodelphis blainvillei. Schmiegelow (1990) presented more information on this species from the southern coast of São Paulo State. During a two-year beach survey, from April 1986 to April 1988, Schmiegelow collected 20 stranded individuals, most of which were found in an advanced

${ }^{1}$ Projeto Atlantis, Departamento de Ecologia Geral, Instituto de Biociências, Universidade de São Paulo. Rua do Matão, 321, Cidade Universitária, São Paulo, SP, Brasil, 05508-900. Corresponding author: marcosos@usp.br.

${ }^{2}$ Centro de Estudos sobre Encalhes de Mamíferos Marinhos (CEEMAM). Avenida Pinheiro Machado, 1033/13, José Menino, Santos, SP, Brasil, 11075-003.

${ }^{3}$ FUNDAMAR (Fundação Museu de História, Pesquisa e Arqueologia do Mar), Av. Vereador Antônio Borges, 1905, Praia Grande, São Sebastião, SP, Brasil, 11600-000. 
state of decomposition. The condition of these carcasses presented difficulties in the development of broader studies. Schmiegelow provided cranial measurements of 12 individuals and described the superficial analyses of the stomach contents from two individuals, from which he identified 85 otoliths belonging to shortfin croakers (Isopisthus parvipinnis), drums (Stellifer rastrifer, S. brasiliensis, Stellifer sp.), and four cephalopod beaks of the squids, Doryteuthis plei and Lolliguncula brevis. Santos (1997) presented a brief description of P. blainvillei stranding records along the coast of São Paulo State and emphasized the problems of live strandings. Further observations of this species in the coastal waters of São Paulo State have been presented at scientific meetings since the middle of the 1990s, but remain unpublished. This paper presents data on P. blainvillei that were collected recently along the coast of São Paulo State.

\section{Material and Methods}

Data, collected by different research groups involved in marine mammal stranding surveys along the three main regions of São Paulo State, were combined and examined. The three collaborating research groups were: Projeto Atlantis (PA), based at São Paulo; Centro de Estudos sobre Encalhes de Mamíferos Marinhos (CEEMAM), based at Santos; and Fundação Museu de História, Pesquisa e Arqueologia do Mar (FUNDAMAR), based at São Sebastião. PA has been surveying Ilha Comprida and Ilha do Cardoso beaches at the southern coast of São Paulo State, near Cananéia $\left(25^{\circ} 00^{\prime} \mathrm{S}, 48^{\circ} 01^{\prime} \mathrm{W}\right.$ ) (see Figure 1), for marine mammal strandings since 1995. From May 1996 to September 1998, 90km of beaches was surveyed twice a month. On two occasions local residents brought incidentally captured individuals to the research group. Since 1997, CEEMAM has been surveying marine mammal strandings along the central coast of São Paulo State, known as "Baixada Santista". The studied area includes the sector from Bertioga $\left(23^{\circ} 59^{\prime} \mathrm{S}, 46^{\circ} 15^{\prime} \mathrm{W}\right)$ to Peruíbe $\left(24^{\circ} 20^{\prime} \mathrm{S}, 47^{\circ} 00^{\prime} \mathrm{W}\right)$, which is near Santos and Guarujá (Figure 1). Due to the impracticality of conducting monthly surveys along the beaches of this area, the strategy adopted included the distribution of flyers and posters at museums, aquariums, regional lifeguard headquarters and other institutions along the coast. On three occasions local fishermen brought to CEEMAM franciscana that were killed incidentally by gillnets while fishing in local waters. FUNDAMAR has been doing similar investigations on marine mammals at the northern coast of São Paulo since 1994 and has adopted the same strategy of CEEMAM. Most records come from São Sebastião $\left(23^{\circ} 49^{\prime} \mathrm{S}, 45^{\circ} 24^{\prime} \mathrm{W}\right)$. In addition to new data, the primary author examined museums, newspaper files and other institutions in São Paulo that could provide unpublished data on cetacean records along the coast in 1993.

\section{Results}

Between 1987 and 2001, 109 records of P. blainvillei along São Paulo State coast were reported. Most of the records were from 1996 to 2001. Ninety-eight events were strandings of single individuals, of which 70 were adults or juveniles and 28 were calves (Figure 2). The total length of these dolphins varied from 50 to $145 \mathrm{~cm}(100.7 \pm 24.6 \mathrm{~cm} ; \mathrm{n}=79)$. The number of reported strandings was significantly different during the seasons $\left(x^{2}=20.8 ; \mathrm{P}<0.01\right)$. Strandings were more frequent during the summer, spring and winter months (see Figure $3)$, than in autumn. No seasonal differences were observed in the number of calves that stranded $\left(x^{2}=2.86 ; \mathrm{P}>0.05\right)$. From individuals in which gender could be determined $(n=53)$, males represented the significant majority $\left(x^{2}=9.0 ; \mathrm{P}<0.01\right)$. Six live strandings (all calves) were observed: four at Santos, one at Ubatuba and one at Cananéia. In addition to the stranding records, 10 individuals that were killed incidentally by gillnets were brought to us by fishermen: four from Cananéia and six from Santos. Furthermore, a swimmer captured a wounded calf as it approached the shallow waters at Guaecá beach, São Sebastião.

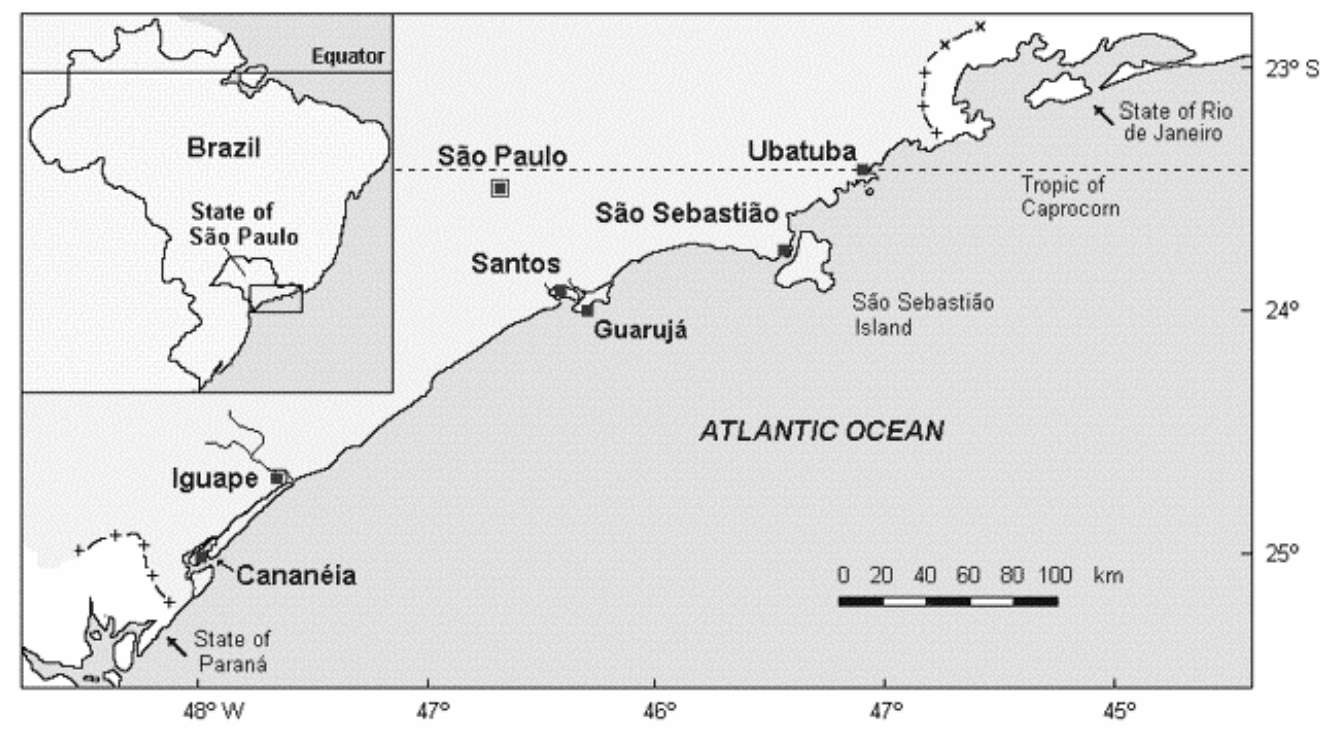

Figure 1. Map of the coastal waters of São Paulo State where Pontoporia blainvillei has been reported since 1961. The southern coast is represented by Cananéia and Iguape, the central coast by Santos and Guarujá, and the northern coast by São Sebastião and Ubatuba. 


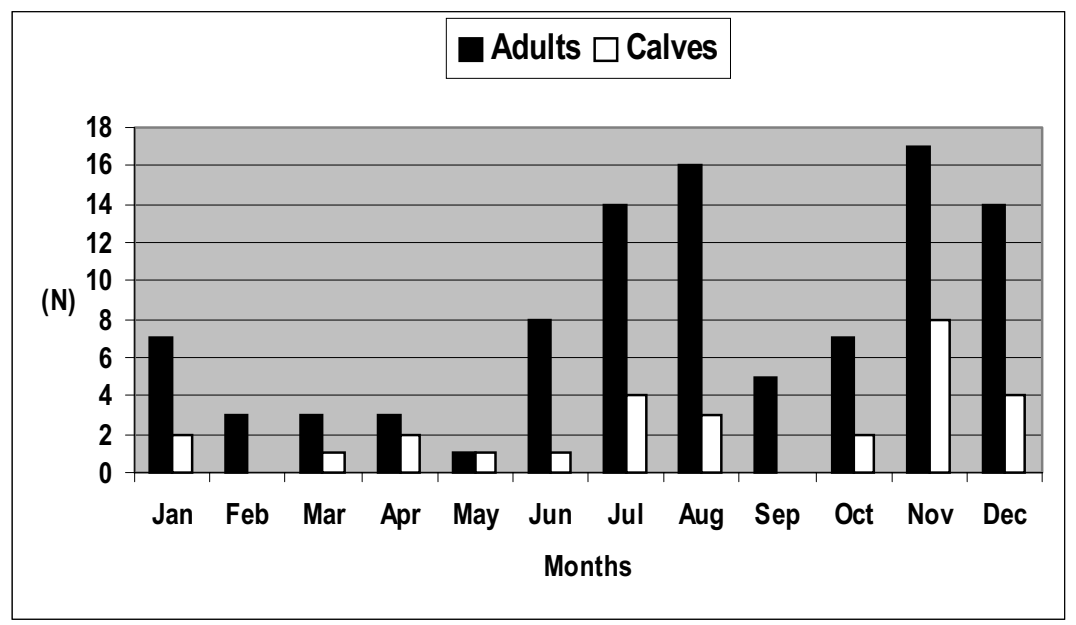

Figure 2. Distribution of Pontoporia blainvillei stranding records (n=98) from 1987 to 2000 at São Paulo State coast along the months of the year. Adults $(n=70)$ and calves $(n=28)$ are represented separately.

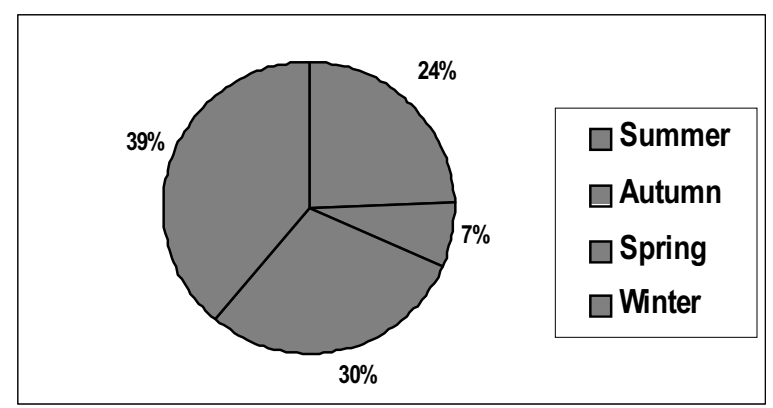

Figure 3. Distribution of Pontoporia blainvillei stranding records ( $\mathrm{n}=98)$ from 1987 to 2000 at São Paulo State coast along the seasons of the year.

\section{$\underline{\text { Regional Summaries }}$}

Southern coast (Ilha Comprida and Ilha do Cardoso, close to Ilha de Cananéia)

Records along the southern coast are presented in Table 1. Twelve individuals were reported stranded. One was a $66 \mathrm{~cm}$ long female neonate that was found alive. It was noticed on November 1999 at Ilha do Cardoso and immediately returned to local coastal waters. Most of the other individuals were highly decomposed, which prevented the determination of gender. The total length of stranded individuals varied from 66 to $133 \mathrm{~cm}(107.1 \pm 22.2$ $\mathrm{n}=7$ ) and age estimates of seven individuals based on Growth Layer Group counts varied from 2 to 5 years (Table 1). In addition, four dolphins captured incidentally were recorded. On 25 May 1999, the carcass of a $130 \mathrm{~cm}$ long female was presented to PA researchers by a local fisherman, who had captured it in his gillnet. On 5 June 2001, another fisherman caught three juveniles incidentally along Ilha Comprida's coastal waters and brought them to PA. These dead individuals, two females and one male with 78 to $92 \mathrm{~cm}$ long, were captured in the same net. No details on capture location or net characteristics were obtained.
Table 1. Franciscana (Pontoporia blainvillei) records along the south coast of São Paulo State between 1996 and 2001. A live stranding of a calf is marked by $\theta$. Incidentally captured individuals are marked by $\bullet$.

\begin{tabular}{ccccc}
\hline Date & Stranding location & CT $(\mathrm{cm})$ & Sex & $\begin{array}{c}\text { Age } \\
\text { (GLGs) }\end{array}$ \\
\hline $17 / 07 / 96$ & Ilha do Cardoso & & & 05 \\
$17 / 07 / 96$ & $\begin{array}{c}\text { Ilha do Cardoso } \\
\text { Ilha Comprida }\end{array}$ & 120 & & 03 \\
$30 / 07 / 96$ & Ilha do Cardoso & & & 04 \\
$31 / 07 / 96$ & Ilha do Cardoso & 133 & & 04 \\
$31 / 07 / 96$ & Ilha Comprida & & & \\
$23 / 08 / 96$ & Ilha Comprida & 100 & & \\
$23 / 08 / 96$ & Ilha do Cardoso & 100 & & \\
$09 / 10 / 96$ & Ilha Comprida & 125 & & 03 \\
$10 / 03 / 97$ & Ilha Comprida & & $\mathrm{M}$ & 06 \\
$11 / 04 / 97$ & Ilha Comprida & 106 & & 02 \\
$30 / 09 / 97$ & off Ilha Comprida $(\bullet)$ & 130 & $\mathrm{~F}$ & \\
$20 / 05 / 99$ & Ilha do Cardoso $(\theta)$ & 66 & $\mathrm{~F}$ & \\
$20 / 11 / 99$ & off Ilha Comprida $(\bullet)$ & 78 & $\mathrm{~F}$ & \\
$05 / 06 / 01$ & off Ilha Comprida $(\bullet)$ & 90 & $\mathrm{~F}$ & \\
$05 / 06 / 01$ & off Ilha Comprida $(\bullet)$ & 92 & $\mathrm{M}$ & \\
$05 / 06 / 01$ & & & & \\
\hline
\end{tabular}

Central coast (Santos, Guarujá, Praia Grande, Mongaguá, Itanhaém, Bertioga and Peruíbe)

A total of 61 strandings were recorded from the "Baixada Santista" region (Table 2). Most records were reported 
Table 2. Franciscana (Pontoporia blainvillei) records along the central coast of São Paulo State between 1988 and 2001. Individuals that showed evidence of incidental capture are marked by the symbol $\Psi$. Live stranded calves are marked by $\theta$ and three individuals were killed incidentally and provided by fishermen are indicated by $\bullet$.

\begin{tabular}{|c|c|c|c|}
\hline Date & Report Location & $\mathrm{CT}(\mathrm{cm})$ & Sex \\
\hline $29 / 07 / 88$ & Santos & & \\
\hline $14 / 12 / 88$ & São Vicente & & \\
\hline $02 / 08 / 94$ & Peruíbe & 100 & \\
\hline $05 / 96$ & Praia Grande $(\theta)$ & 71 & M \\
\hline $24 / 04 / 97$ & Guarujá $(\theta)$ & 74 & $\mathrm{~F}$ \\
\hline $07 / 03 / 97$ & Santos & & \\
\hline $15 / 06 / 97$ & Praia Grande & 120 & \\
\hline $18 / 07 / 97$ & Itanhaém & 106.5 & M \\
\hline $30 / 09 / 97$ & Peruíbe & 106 & \\
\hline $12 / 10 / 97$ & Bertioga $(\Psi)$ & 62.5 & M \\
\hline $26 / 06 / 98$ & Santos & 107 & M \\
\hline $07 / 98$ & Guarujá & 84 & M \\
\hline $07 / 98$ & Guarujá & 125 & $\mathrm{~F}$ \\
\hline $26 / 08 / 98$ & Mongaguá & $130 *$ & $\mathrm{~F}$ \\
\hline $11 / 09 / 98$ & Santos & 119 & M \\
\hline $15 / 10 / 98$ & São Vicente & & \\
\hline $02 / 11 / 98$ & Praia Grande & 102 & \\
\hline $06 / 11 / 98$ & Praia Grande $(\Psi)$ & 60 & M \\
\hline $30 / 11 / 98$ & Santos $(\Psi)$ & 60 & \\
\hline $20 / 11 / 98$ & Bertioga $(\Psi)$ & 74.5 & $\mathrm{~F}$ \\
\hline $20 / 11 / 98$ & Bertioga & 112 & M \\
\hline $02 / 12 / 98$ & Praia Grande & 120 & M \\
\hline $04 / 12 / 98$ & Santos & 122.5 & M \\
\hline $07 / 12 / 98$ & Bertioga & 141 & $\mathrm{~F}$ \\
\hline $14 / 12 / 98$ & Santos $(\Psi)$ & 59 & M \\
\hline $23 / 12 / 98$ & Praia Grande $(\Psi)$ & 73 & \\
\hline $01 / 01 / 99$ & Santos & 126 & \\
\hline 28/03/99 & Guarujá & 88 & M \\
\hline $03 / 07 / 99$ & Praia Grande & 95 & M \\
\hline $10 / 08 / 99$ & Guarujá & & \\
\hline $11 / 08 / 99$ & Peruibe & & \\
\hline $17 / 11 / 99$ & Santos $(\Psi)$ & 62 & \\
\hline $27 / 11 / 99$ & Praia Grande & 112 & M \\
\hline $02 / 12 / 99$ & Mongaguá & 120 & M \\
\hline $12 / 12 / 99$ & São Vicente & & M \\
\hline $21 / 12 / 99$ & Praia Grande $(\Psi)$ & 71 & $\mathrm{~F}$ \\
\hline $11 / 01 / 00$ & Praia Grande & 129 & $\mathrm{~F}$ \\
\hline $26 / 01 / 00$ & Guarujá & 128 & $\mathrm{~F}$ \\
\hline $18 / 02 / 00$ & Praia Grande & 108 & \\
\hline $14 / 06 / 00$ & Praia Grande & 120 & \\
\hline $15 / 06 / 00$ & Praia Grande & 128 & $\mathrm{~F}$ \\
\hline $19 / 06 / 00$ & Peruíbe & 94 & \\
\hline $25 / 06 / 00$ & Itanhaém & 102 & \\
\hline $14 / 07 / 00$ & Praia Grande & 102 & \\
\hline $20 / 07 / 00$ & Praia Grande & 100 & \\
\hline $29 / 07 / 00$ & Peruíbe & & \\
\hline $30 / 07 / 00$ & Praia Grande & 80 & $\mathrm{~F}$ \\
\hline $31 / 07 / 00$ & Mongaguá (•) & 113 & M \\
\hline $12 / 08 / 00$ & Santos & 110 & $\mathrm{~F}$ \\
\hline $15 / 08 / 00$ & Santos & 98 & M \\
\hline $17 / 08 / 00$ & Santos & $140^{* *}$ & $\mathrm{~F}$ \\
\hline $21 / 08 / 00$ & Itanhaém & 100 & \\
\hline $23 / 08 / 00$ & Praia Grande & 120 & M \\
\hline $26 / 08 / 00$ & Mongaguá $(\Psi, \bullet)$ & 115 & M \\
\hline $30 / 08 / 00$ & Santos & 98 & M \\
\hline $19 / 08 / 00$ & Praia Grande & 115 & M \\
\hline 09/09/00 & Mongaguá ( $\Psi, \bullet)$ & 120 & M \\
\hline $28 / 09 / 00$ & Guarujá & & \\
\hline $02 / 10 / 00$ & Itanhaém & 125 & \\
\hline $25 / 11 / 00$ & Praia Grande $(\theta)$ & 50 & $\mathrm{~F}$ \\
\hline $01 / 01 / 01$ & Guarujá $(\theta)$ & 60 & M \\
\hline $01 / 01 / 01$ & Guarujâ & 60 & M \\
\hline 05/04/01 & Bertioga & 95 & $\mathrm{~F}$ \\
\hline $17 / 08 / 01$ & Peruíbe & 110 & M \\
\hline
\end{tabular}

$\left(^{*}\right)$ with a $33 \mathrm{~cm}$ long fetus, $\left({ }^{* *}\right)$ with a $49 \mathrm{~cm}$ long fetus between 1997 and 2001. Ten individuals showed signs of incidental capture by gillnets. The total length of stranded individuals varied from 50 to $141 \mathrm{~cm}(99.5 \pm 24.4 ; n=52)$. Also, three individuals that were killed incidentally by gillnets were brought to CEEMAM by local fishermen (see Table 2). On 25 January 1993, three individuals were captured incidentally in the same net and landed at a local beach at Bertioga. Four live stranding records (all calves) were reported. These calves were collected just after the stranding by local onlookers, but they died 5 to 36 hours after being kept in small pools for rehabilitation. Two of the females recovered in winter months were pregnant with fetuses that were $33 \mathrm{~cm}$ and $49 \mathrm{~cm}$ long.

\section{Northern coast (São Sebastião, Ilha Bela, Caraguatatuba and Ubatuba)}

At São Sebastião and nearby areas, 27 stranding records were gathered (Table 3). Most records were reported from 1994 to 2000. Total lengths varied from 60 to $145 \mathrm{~cm}(101.4 \pm 26.7 ; n=20)$. Five individuals showed evidence of net entanglement. A neonate calf stranded alive at Ubatuba in 1996, but died after 48 hours in a small pool under the care of local volunteers. On 13 January 1997, a 74cm long male calf showing body wounds caused by a boat's propeller was retrieved from shallow waters by a swimmer at Guaecá beach, São Sebastião. It was released near the "capture" area a few hours later and did not show any obvious difficulties while swimming away from the boat. There was no further report of its presence (dead or alive) at local beaches after the release. No artificial tag was used to identify the individual.

Table 3. Franciscana (Pontoporia blainvillei) stranding records along the northern coast of São Paulo State between 1987 and 2001. A live stranding of a calf is marked by $\theta$.

\begin{tabular}{cccc}
\hline Date & Report Location & CT $(\mathrm{cm})$ & Sex \\
\hline $13 / 09 / 87$ & Ubatuba & 100 & \\
$20 / 12 / 88$ & Ubatuba & 124 & $\mathrm{M}$ \\
$13 / 06 / 94$ & São Sebastião & 92.5 & $\mathrm{~F}$ \\
$22 / 11 / 94$ & São Sebastião & 145 & \\
$22 / 11 / 94$ & São Sebastião & & \\
$26 / 11 / 94$ & São Sebastião & 70 & \\
$14 / 11 / 95$ & São Sebastião & 106 & $\mathrm{M}$ \\
$26 / 11 / 95$ & São Sebastião & 68 & $\mathrm{~F}$ \\
$29 / 02 / 96$ & São Sebastião & & \\
$28 / 06 / 96$ & São Sebastião & 140 & \\
$07 / 96$ & Ubatuba $(\theta)$ & 68 & $\mathrm{~F}$ \\
$14 / 08 / 96$ & Ilha Bela & 89 & \\
$04 / 11 / 96$ & Caraguatatuba & 117 & $\mathrm{~F}$ \\
$05 / 12 / 96$ & Ilha Bela & & \\
$07 / 97$ & São Sebastião & & \\
$18 / 10 / 97$ & Ilha Bela & 115 & \\
$29 / 08 / 98$ & Ilha Bela & 116 & $\mathrm{~F}$ \\
$28 / 10 / 98$ & São Sebastião & 64 & \\
$20 / 12 / 98$ & Ubatuba & 124 & $\mathrm{M}$ \\
$09 / 11 / 99$ & São Sebastião & $127^{*}$ & $\mathrm{~F}$ \\
$09 / 11 / 99$ & São Sebastião & 60 & $\mathrm{M}$ \\
$11 / 12 / 99$ & São Sebastião & 73 & $\mathrm{~F}$ \\
$11 / 01 / 00$ & São Sebastião & 122 & $\mathrm{M}$ \\
$22 / 01 / 00$ & São Sebastião & & \\
$08 / 02 / 00$ & São Sebastião & & \\
$31 / 10 / 00$ & São Sebastião & 108 & $\mathrm{~F}$ \\
$12 / 00$ & São Sebastião & & \\
\hline
\end{tabular}

$\left.{ }^{*}\right)$ with a $60 \mathrm{~cm}$ long fetus 


\section{Discussion}

Our data showed that $P$. blainvillei strandings occur yearround along São Paulo State coast (Figure 2). However, the tendency of lower incidences during autumn months (Figure 3) should be investigated further. In all three sectors, the investigation efforts were evenly distributed along time and space. Because other studies have shown incidental captures as one of the main reasons for stranding, studies of the franciscana and local fishing efforts throughout the year must be conducted. Only at Praia Grande (near Santos) have such efforts been conducted (Bertozzi and Zerbini, 2002). The significant differences in the sex ratio of stranded individuals also require further studies to confirm this observation. On many occasions it was not possible to determine the gender of the stranded individuals because of the state of decomposition. However, muscle samples were collected $(n=14)$ so their gender may be resolved in the near future using DNA analyses.

Based on the 79 stranded individuals that had their total lengths measured, and the ten incidentally-captured individuals, it appears that adult franciscana of the coastal waters of São Paulo State can reach at least $145 \mathrm{~cm}$ in total length. Detailed studies comparing the growth curves of franciscana from São Paulo State with those from other regions may bring relevant information on stock characterization delineation. For example, it is already known that franciscanas of northern Santa Catarina, Brazil, were considered smaller than those found south of that state (see Pinedo, 1991; Ramos et al., 2000; Rosas, 2000). Secchi et al. (in press) suggested that the northern stock may be further split into two other distinct units and they recommended investigations in areas, such as the coastal waters of São Paulo State, where few data is available. In the present study, age was investigated only for the southern sector of São Paulo State (Table 1). The ages of seven individuals were estimated between two and six years (most were young). Like other areas, the incidental capture rate of franciscana may be high in São Paulo waters and highly biased towards young individuals (Rosas, 2000).

The observed data on calving seasonality corroborate observations made in northern Rio de Janeiro, where franciscanas appear to reproduce year round with no evident seasonal peak (Ramos et al., 2000). However, because the sample size of the present study was small, further investigations on reproduction are needed in order to confirm this seasonal pattern and compare with franciscana of the southern population, which has marked seasonal reproduction with peaks in spring and summer (see Kasuya and Brownell, 1979; Pinedo et al., 1989; Danilewicz et al., 2000).

Although six calves stranded alive, five of them died shortly after being kept in small pools (one was released alive in local waters). In São Paulo State, there are neither adequate facilities to maintain dolphins, nor knowledgeable and experienced people to provide medical attention for dolphins that strand alive. Nevertheless, rehabilitation of stranded dolphins is still attempted. Although these experiences can contribute to our knowledge of franciscana, we believe that live stranded individuals should be replaced as soon as possible back into the shallow coastal waters and as close as possible to the stranding location. Regardless of the reason(s) for stranding, unprepared volunteers and inadequate facilities do not represent the best choice for the dolphins. On one occasion a stranded calf was released back into coastal waters shortly after the stranding event. It moved well and quickly into deeper waters. Unfortunately, no artificial tags were available for monitoring the status of the released calf. We believe the chance of survival is greater for franciscana in their natural habitat compared to being held in inadequate conditions. However, handling live cetaceans in Brazil is an issue that deserves more attention and discussion, mainly because of inadequate facilities, inexperienced personnel and inadequate policies dealing with the management of live-stranded marine mammals in this country. The calf, which was recovered after being struck by a boat's propeller, revealed another threat of concern. The northern coast of São Paulo, where this calf was found, experiences a relatively high amount of tourism during the summer months. It is estimated that between 60 and 110 high-speed boats use the coastal waters of São Sebastião during the summer months each year (Carneiro, 1995). This activity poses another threat to this coastal dolphin species.

The predominance of brackish waters (see Emílsson, 1961; Matsuura, 1986) which is preferred by P. blainvillei to avoid predators (Siciliano and Santos, 1994), makes the coast of São Paulo State a potential area for the development of research on this species. The large number of strandings reported at Santos, where coastal waters are darker than the northern coast, may provide a potential location to conduct studies. The "Baixada Santista" region needs special attention because of the relatively high number of stranding reports in recent years, easy accessibility to stranded and fresh animals, the close vicinity to small fishermen communities, and easy access to facilities to perform detailed necropsies. The northern and the southern coasts of São Paulo also have a potential for future studies, but first, effort to collect incidentally captured animals is needed. All information that is collected and organized should be standardized amongst different researchers. Because of the lack of understanding of this species in the coastal waters of São Paulo State, it is urgent that rigorous research and conservation politics directed towards this species be developed immediately in this region.

\section{Acknowledgements}

The authors express their gratitude to Eduardo R. Secchi and John Wang for their critical and detailed review and important suggestions to improve the final version of this manuscript. The authors thank Alexandre Simonelli (Folha de São Paulo), Raimundo Rosa (A Tribuna de Santos), Daniela Gurgel, Renata Fernanda and Reginaldo Pupo (Imprensa Livre de São Sebastião), José Valpereiro (Jornal Vale Paraibano), Virgílio Nunes (Projeto Toninhas-SP) who provided data and good quality photos of some P. blainvillei strandings. We also thank Berenice Gallo (Projeto TAMAR), 
André Rossi (Fundação ANIMALIA), Ana Luiza Machado, Rui Teston, Luiz Bolina Jr. and Sílvio de Angelis Jr. (FUNDAMAR), Claudio G. Tiago and Valeria Flora Hadel (CEBIMar), Paulo de Tarso (Aquário Municipal de Santos) and the firearms headquarters from São Sebastião and Santos for always reporting cetacean stranding events. Renata M. A. Ramos helped M. C. O. S. to estimate the ages of franciscana collected at the southern coast of São Paulo. Eduardo R. Secchi supported each of the three research groups with references, suggestions and encouragement to investigate marine mammals at São Paulo, as well as suggested some ideas to improve the early drafts of this manuscript.

\section{References}

Bertozzi, C. and Zerbini, A.N. (2002) Incidental mortality of franciscana, Pontoporia blainvillei, in the artisanal fishery of Praia Grande, São Paulo State, Brazil. Latin American Journal of Aquatic Mammals (special issue) 1: 153-160.

Besnard, W. (1950) Considerações gerais em torno da região lagunar de Cananéia-Iguape I. Boletim do Instituto Paulista de Oceanografia 1: 9-26.

Brownell Jr., R.L. (1975) Progress report on the biology of the franciscana dolphin, Pontoporia blainvillei, in Uruguayan waters. Journal of the Fisheries Research Board of Canada 32: 1073-1078.

Carneiro, A.G. (1995) Guia Mar São Paulo. Editora Grupo 1 Ltda, São Paulo.

Carvalho, C.T. de (1961) Stenodelphis blainvillei na costa central do Brasil, com notas osteológicas (Cetacea, Platanistidae). Revista Brasileira de Biologia 21(1): 443-454

CODESP (1975) Port of Santos, Brazil - 100 years (1892-1992). Compainha das Docas do Estado de São Paulo (CODESP), Santos, Special Issue 25pp.

Crespo, E.A, Harris, G. and González, R. (1998) Group size and distributional range of the franciscana, Pontoporia blainvillei. Marine Mammal Science 14: 845-849.

Danilewicz, D.S., Secchi, E.R., Ott, P.H. and Moreno, I. (2000) Analysis of the age at sexual maturity and reproductive rates of franciscana (Pontoporia blainvillei) from Rio Grande do Sul, southern Brazil. Comunicações do Museu de Ciências e Tecnologia, PUCRS 13: 89-98.

Di Beneditto, A.P.M. (1997) Captura acidental de pequenos cetáceos em rede de espera: uma ameaça às populações do norte do Rio de Janeiro? Master Dissertation, Universidade Estadual do Norte Fluminense, Campos dos Goytacazes. 91pp.

Di Beneditto, A.P.M. (2000) Ecologia alimentar de Pontoporia blainvillei $e$ Sotalia fluviatilis (Cetacea) na Costa Norte do Rio de Janeiro, Brasil. Doctoral Thesis. Universidade Estadual do Norte Fluminense, Campos dos Goytacazes. 173pp.

Emílsson, I. (1961) The shelf and coastal waters off southern Brazil. Boletim do Instituto Paulista de Oceanografia 11(2): 101-112.

Fitch, J.E. and Brownell Jr., R.L. (1971) Food habits of the franciscana, Pontoporia blainvillei (Cetacea, Platanistidae) from South America. Bulletin of Marine Science 21: 626-636.

Kasuya, T. and Brownell Jr., R.L. (1979) Age determination, reproduction, and growth of franciscana dolphin, Pontoporia blainvillei. Scientific Reports of the Whaling Research Institute, 31: 45-67.

Matsuura, Y. (1986) Contribuição ao estudo da estrutura oceanográfica da região sudeste entre Cabo Frio (RJ) e Cabo de Santa Marta Grande (SC). Ciência e Cultura 38(8): 1439-1450.

Moreira, L.M. and Siciliano, S. (1991) Northward extension range for Pontoporia blainvillei. Page 50 in Abstracts, IX Biennial Conference on the Biology of Marine Mammals, 5-9 December, Chicago.

Moreno, I.B., Ott, P.H. and Danilewicz, D.S. (1997) Análise preliminar do impacto da pesca costeira sobre Pontoporia blainvillei no litoral norte do Rio Grande do Sul, sul do Brasil. Pages 31-41 in Pinedo,
M.C. and Barreto A.S. (Eds) Anais do $2^{\circ}$ Encontro sobre Coordenação de Pesquisa e Manejo da Franciscana. Ed. FURG, Rio Grande.

Pinedo, M.C. (1991) Development and variation of the franciscana Pontoporia blainvillei. Ph.D. dissertion, University of California, Santa Cruz. 406pp.

Pinedo, M.C., Praderi, R. and Browell Jr., R.L. (1989) Review of the biology and status of the franciscana Pontoporia blainvillei. Pages 46-51 in Perrin, W.F., Brownell Jr., R.L., Kaiya, Z. and Jiankang(Eds) Biology and Conservation of the River Dolphins. IUCN SSC 3, Gland.

Ramos, R.M.A. (1997) Determinação de idade e biologia reprodutiva de Pontoporia blainvillei $e$ da forma marinha de Sotalia fluviatilis (Cetacea: Pontoporiidae e Delphinidae) no norte do Rio de Janeiro. Master Dissertation, Universidade Estadual do Norte Fluminense, Rio de Janeiro. 95pp.

Ramos, R.M.A., Di Benedito, A.P.M. and Lima, N.R.W. (2000) Growth parameters of Pontoporia blainvillei in northern Rio de Janeiro, Brazil. Aquatic Mammals 26:65-75

Rosas, F.C.W. (2000) Interações com a pesca, mortalidade, idade reprodução e crescimento de Sotalia guianensis e Pontoporia blainvillei (Cetacea, Delphinidae e Pontoporiidae) no litoral sul do Estado de São Paulo e litoral do Estado do Paraná, Brasil. Doctoral Thesis. Universidade Federal do Paraná, Curitiba. 145pp.

Santos, M.C. de O. (1997) Franciscana, Pontoporia blainvillei (Cetacea, Pontoporiidae) ao longo do litoral de São Paulo: a urgência da aplicação de programas adequados de pesquisa e de conservação. Pages 405406 in Abstracts, VII Congresso Latino-americano sobre Ciências do Mar, 22-26 September, Santos.

Schaeffer-Novelli, Y., Mesquita, H. and Cintrón-Molero, G. (1990) The Cananéia lagoon estuarine system, São Paulo, Brazil. Estuaries 13(2): 193-203.

Schmiegelow, J.M.M. (1990) Estudo sobre cetáceos odontocetos encontrados em praias da região entre Iguape (SP) e baia de Paranaguá $(P R)$, com especial referência a Sotalia fluviatilis (Gervais, 1853)(Delphinidae). Master DIssertation, Universidade de São Paulo, São Paulo. 149pp.

Secchi, E.R., Zerbini, A.N., Bassoi, M., Dalla Rosa, L., Möller, L.M. and Rocha-Campos, C.C. (1997) Mortality of franciscanas, Pontoporia blainvillei, in coastal gillnets in southern Brazil: 19941995. Reports of the International Whaling Commission 47:653-658.

Secchi, E.R., Wang, J.Y., Murray, B., Rocha-Campos, C.C. and White, B.N. (1998) Populational differentiation in the franciscana (Pontoporia blainvillei) from two geographical locations in Brazil as determined from mitochondrial DNA control region sequences. Canadian Journal of Zoology 76(9): 1622-1627.

Secchi, E.R., Ott, P.H., Crespo, E.A., Kinas, P.G., Pedraza, S.N. and Bordino, P. (2001) A first estimate of franciscana (Pontoporia blainvillei) abundance off southern Brazil. Journal of Cetacean Research and Management 3: 95-100.

Secchi, E.R., Danilewicz, D.S. and Ott, P.H. (in press) Applying the phylogeographic concept to identify franciscana dolphin stocks: implications to meet management objectives. Journal of Cetacean Research and Management

Siciliano, S. and Santos, M.C. de O. (1994) Considerações sobre a distribuição da franciscana Pontoporia blainvillei no litoral sudeste do Brasil. DT 05, $2^{\circ}$ Encontro sobre Coodenação de Manejo e Pesquisa da Franciscana, 22-23 October, Florianópolis.

SMA (1999) Mapeamento dos Ecossistemas Costeiros do Estado de São Paulo. Special Report prepared by the Secretaria do Meio Ambiente do Estado de São Paulo (SMA), São Paulo. 108pp.

Zanelatto, R.C. (1997) Captura Acidental de Toninha Pontoporia blainvillei Gervais \& D'Orbigny, 1844 (Cetacea, Pontoporiidae) no litoral do Estado do Paraná, Brasil. Pages 23-30 in Pinedo, M.C. and Barreto A.S. (Eds) Anais do $2^{\circ}$ Encontro sobre Coordenação de Pesquisa e Manejo da Franciscana. Ed. FURG, Rio Grande.

Received 14 November 2001. Accepted 19 April 2002. 